\title{
Sensibilidade, educação e trabalho em O Emílio de Rousseau
}

Henrique Segall Nascimento Campos ${ }^{1}$

\section{Resumo:}

O presente trabalho tem como meta explorar, em geral, o tema do sensualismo em Rousseau, como expressão de uma tentativa de explicar os conhecimentos adquiridos pelo homem. Isso significaria analisar e explicar as origens e o desenvolvimento das faculdades da alma, ao lado da capacidade do homem de conhecer, nos textos em que o problema estiver presente, associado a isso a capacidade do homem de pensar, sua subjetividade, com os desdobramentos para o campo da moral. O tema do conhecimento será analisado explorado no campo de investigação onde ele é elemento fundamental, ou seja, na educação. Com isso, o processo de complexificação do conhecimento, sensações e ideias, bem como o desenvolvimento da razão e das demais faculdades, deverão ser pensados em associação com o ordenamento natural, com as "categorias" de força, movimento e necessidade. Nesse sentido, de modo específico, nossa pretensão é chegar a indicar que a liberdade, por exemplo, pode ser lida de uma forma espiritualizada a partir da análise destes pressupostos epistemológicos, a ponto de influenciar o modo de ser do homem e, por conseguinte, seu modo de pensar, quando são associadas ao problema da educação, da sensibilidade e do trabalho, especificamente, no livro III do $O$ Emílio.

Palavras-chave: Sensibilidade; educação; trabalho; conhecimento.

\section{Sensitivity, education and work in Emile of Rousseau}

\begin{abstract}
:
The present work aims to explore in general the theme of sensualism in Rousseau, as an expression of an attempt to explain the knowledge acquired by man. This would mean analyzing and explaining the origins and development of the faculties of the soul, alongside man's capacity to know, in the texts in which the problem is present associated with it the capacity of man to think his subjectivity with the unfolding the field of morality. The subject of knowledge will be analyzed explored in the field of research where it is fundamental element that is in education. In this way the process of the complexification of knowledge (sensations and ideas) as well as the development of reason and other faculties should be thought in association with natural ordering with the "categories" of force, movement,

1 Doutor pela Universidade Federal de Minas Gerais (UFMG). E-mail: henriquesegall@gmail.com.
\end{abstract}


and necessity. In this sense, in a specific way, our pretension is to arrive to indicate that freedom, for example, can be read in a spiritualized way from the analysis of these epistemological assumptions, to the point of influencing man's way of being and therefore their way of thinking, when they are associated with the problem of education, sensitivity and work specifically in Book III of Emile.

Key words: Sensibility; education; work; knowledge.

\section{Introdução}

Desde o momento em que o primeiro produto da iluminação de Vincennes veio a lume, o interesse de Rousseau foi o de sempre investigar as raízes dos problemas por que passaram, ou por que passam, os seres humanos ao longo de seu processo de constituição, acolhendo as mais variadas características, realizando as mais variadas empreitadas, muito embora elas não tenham contribuído, de fato, para a glória e a plenitude da espécie. Nesse sentido, a perseguição dos problemas sociais, a moral e a corrupção humana, disposta numa enorme diversidade de gêneros textuais, foi tamanho que teria levado a intérpretes do autor, ao longo do século XX, a valorizá-lo e considerá-lo como pensador que, contrariamente àquilo que se pensava dele nos séculos anteriores, teria produzido um sistema, cuja continuidade e repetição de temas e conceitos é percebido pela leitura de seus principais textos, $1^{\circ}$ Discurso, $2^{\circ}$ Discurso, Emílio, Contrato social e Ensaio sobre a origem das línguas. Por mais que leituras contemporâneas tenham realizado um trabalho amplo de aproximação de seu ideário com as ciências de seu tempo, contribuindo, por isso, com uma amplificação do entendimento de quem era, afinal, Rousseau como pensador, como teórico, como construtor de conceitos, o espírito que anima seu ideário não se dissipa, não desaparece. Intérpretes, buscando trazer à tona, por meio de leituras comparadas, a clarificação dos debates enfrentados pelos filósofos do século XVIII, ao se referirem a Rousseau reforçam este espírito, com o qual o próprio genebrino se identificou, o de ter produzido uma obra filosófica unificada.

Por outro lado, é sabido que Rousseau teria aberto debate os mais diversos, sobre os mais diversos problemas em questão no seu tempo. Vargas sugere que

de uma certa maneira, o ateísmo nomeado por Rousseau, como materialismo, não é mais materialista do que teísta: essas duas correntes falam igualmente do primado da matéria do movimento e da ordem. Os materialistas encontram a coesão das três noções na imanência. Os teístas na transcendência. Mas os ateus e teístas se encontram para recusar ao mundo toda 
finalidade moral, toda intenção divina. Nesse afrontamento Rousseau toma partido e se faz tanto inimigo quanto existem campos. Ele sustenta o teísmo contra os ateus ao optar por um deus ordenador, ele se opõe aos teístas e aos ateus ao mesmo tempo dando ao mundo uma significação moral e a recusa de condenar as igrejas. Ele aparece inimigo destes quando ele recusa todo argumento de autoridade e deprecia os dogmas em termos de utilidade política. (VARGAS, 1995, p. 157)

É possível dizer, com isso, que Rousseau teve de dar respostas a tantos autores que talvez um rio de tinta bastaria para dar cabo do problema, de estudos filosóficos sobre o autor e seus "desafetos". Nesse sentido, pode-se verificar que o pensamento do filósofo de Genebra apresenta sinais de ter sido produzido, em certa medida, como rejeição de teses, contrárias não apenas àquelas defendidas por Helvetius apenas, como é evidente textualmente, mas ainda contrárias a um conjunto de outras teses filosóficas dispersas no período. Ainda que não fosse seu interesse principal, ser um polemista e ser um filósofo de "confronto", Rousseau questiona concepções que reduzem as faculdades humanas à sensibilidade física, ao materialismo, preocupa-se com o funcionamento das faculdades humanas subjetivas, rejeita o otimismo quanto a uma educação produtora do homem e as consequências desta no campo da moral e da política.

Quanto a isso, especificamente, o debate com o chamado sensualismo e/ou materialismo e o esforço de clarificação de suas posições foram levados a cabo por Rousseau, embora, ao nosso ver, tenha sido pouco explorado, pouco revelado pela historiografia das interpretações do pensador genebrino. Isso se prova, pelo menos em parte, pelas referências feitas nas Cartas escritas da Montanha - texto seguramente produzido como defesa do Emílio e do Contrato social - e na Carta a Christophe de Beaumont $^{2}$, quando ele defende o conteúdo de seu pensamento de modo geral e de sua Profissão de fé3 em particular, da incompreensão generalizada.

\footnotetext{
2 "Após o meu primeiro Discurso, fui o homem de paradoxos, que brincava de provar coisas em que não acreditava. Após a minha Carta sobre a música francesa, fui o inimigo declarado da nação, pouco faltando para que me tratassem como subversivo - dir-se-ia que o destino da Monarquia estava ligado à glória da ópera. Após o meu Discurso sobre a desigualdade, fui ateu e misantropo; após a Carta a D'Alembert, fui o defensor da moral cristã, após a Heloísa, fui terno e melodioso; hoje sou um ímpio; logo mais, quem sabe, serei um devoto. Assim vai flutuando o tolo público a meu respeito, sabendo tão pouco por que agora me odeia quanto sabia por que me amava anteriormente" (ROUSSEAU, 2005, pp. 40-1).

3 "A profissão do Vigário Saboiano, é composta de duas partes. A primeira, que é a maior, a mais importante, a mais cheia de verdades marcantes e novas, é destinada a combater o moderno materialismo, a estabelecer a existência de Deus e da religião natural, com toda a força da qual o autor é capaz" (ROUSSEAU, 2005, p. 106).
} 
Nessa esteira, quando um leitor mais pretensioso começa um estudo sobre Rousseau, normalmente se dá conta de duas grandes intuições que cortam seus escritos como um todo: uma que diz ser o homem contemporâneo às vezes mal e infeliz, por conta da forma da sociabilidade e das instituições políticas com as quais convive; e outra que garante, embora constatado o quadro presente de infelicidade e maldade generalizadas, ser a natureza humana essencialmente boa e livre. Observado isso e verificado a forte acentuação que dão os comentadores, não sem razão, ao conteúdo moral e político das preocupações intelectuais de Rousseau, notamos que sobraria pouco espaço e interesse para a observação dos pressupostos, da fundamentação desta moralidade e da política, que fazem do genebrino um dos pensadores prediletos dos sociólogos que surgiram no século seguinte. A julgar pela ausência de um escrito dedicado exclusivamente aos problemas de natureza epistemológica e a pressa com que ele passa, na Profissão de fé sobretudo, pela exposição de argumentos e conceitos próximos do modo clássico de se fazer metafísica, esta fundamentação não teria importância. Por outro lado, se entendemos que esse discurso de fundamentação serve de auxílio e ajuda no entendimento da unidade da obra de Rousseau, a sua presença no pano de fundo conceitual deixa de aparecer sem foco e passa a compor o quadro de forma tal que a evidência das grandes intuições passa a gozar, também, de complexidade. Dada, portanto, a dificuldade porque passava Rousseau pela incompreensão de seu pensamento, acreditamos que se consideramos sua filosofia a partir da atenção que ele dá ao desenvolvimento da subjetividade humana, em consonância com a atividade de consciência, bem como ao tema do conhecimento em direção a uma "via epistêmica" - ao assumir alguns aspectos do sensualismo de seu tempo - sua antropologia, sua moral, a política, a crítica à religião, o funcionamento da liberdade, o problema do mal e a necessidade de superação dos limites humanos por uma sociedade politizada seriam melhor compreendidos.

De acordo com o que foi dito, o presente trabalho tem como meta explorar, em geral, o tema do sensualismo em Rousseau, como expressão de uma tentativa de explicar os conhecimentos adquiridos pelo homem. Isso significaria analisar e explicar as origens e o desenvolvimento das faculdades da alma, ao lado da capacidade do homem de conhecer, nos textos em que o problema estiver presente, associado a isso a capacidade do homem de pensar, sua subjetividade, com os desdobramentos para o campo da moral, a principal preocupação do pensamento de Rousseau. O tema do conhecimento, por sua vez, é explorado, mais detidamente, no campo de investigação onde ele é elemento fundamental, ou seja, na educação. Para isso, no Emílio o conhecimento de origem sensível, com 
conteúdo e forma específicos, deverá ser explorado, em consonância com aquilo que foi feito no 20 Discurso, em sua processualidade. Com isso, o processo de complexificação do conhecimento, sensações e ideias, bem como o da razão e demais faculdades, deverão ser expostos sempre pensados em associação com o ordenamento natural, com as "categorias" de força, movimento e necessidade. Nesse sentido, de modo específico, nossa pretensão é chegar a indicar que a liberdade do homem pode ser lida de uma forma espiritualizada a partir da análise destes pressupostos epistemológicos, a ponto de influenciar o modo de ser do homem e por conseguinte seu modo de pensar, quando são associadas, por sua vez, o problema da educação, da sensibilidade e do trabalho no livro III do $O$ Emílio ${ }^{4}$.

\section{O homem na idade do trabalho}

No livro III de seu texto de educação, o genebrino quer marcar a influência da atividade produtiva e da experiência com o trabalho, a determinação de um saber que vai forjar tanto as ciências e a as artes de modo geral, quanto aquelas artes que tenham maior relevância para a humanidade na questão da autossuficiência. Portanto, para esses conhecimentos e o trabalho como fonte de conhecimento de natureza sensível e prática, existe uma utilidade governando as ações e um conhecimento sem intersubjetividade ainda, porque a educação das coisas ainda preside as aquisições. Quer apresentar, por outro lado, o advento de novas faculdades, tais como a razão, por meio da qual o indivíduo vai poder fazer as chamadas associações e comparações, a partir das quais o juízo vai aparecer e uma nova conformidade anímica decorrente deste aspecto ativo do saber. Esse nível de saber será preparatório para os outros níveis de intelecção e abstração, próprios de um saber genuinamente

\footnotetext{
4 Em linhas bem gerais, o projeto de educação proposto por Rousseau no Emílio divide-se em etapas. Para marcar a diferenciação das etapas, o homem em sua expressão física vai se desenvolver, privilegiando aspectos relativos ao uso da força e do movimento, e por outro o homem em sua expressão moral vai se educar ao serem privilegiados conteúdos de informação cujas origens, fundamentalmente, estejam associadas às relações humanas em sociedade, intersubjetivamente. Coerentemente com os tipos de educação, o percurso pedagógico implica na realização dessas modalidades distintas de constituição humana, que deverão ser, sempre, complementares, porque, subjetivamente, as faculdades mentais usadas para pensar seus objetos específicos são qualitativamente dependentes umas das outras. De acordo com isso, mesmo a expressão da subjetividade mais elaborada, depende de uma educação sensível adequadamente constituída para que Emílio seja capaz de pensar questões as mais abstratas, tais como a religião e as regras de moralidade. Quer dizer, esse homem moral que vai ser educado nos modelos indicados nos livros IV e V do Emílio, é decorrente do homem físico, dos livros de I a III, sensivelmente condicionado. Dito isso, partiremos para uma jornada investigativa, para dentro do homem, em busca da subjetividade que ganha complexidade pela paulatina contribuição das informações das sensações e aspectos implicados na sensibilidade, dentre os quais os atributos e princípios essenciais humanos.
} 
abstrato, como o saber religioso. Para expor isso, será necessário contextualizar o estágio do desenvolvimento do sujeito no plano educacional, do indivíduo associado ao ordenamento natural, com a lógica da natureza prevista para esta etapa de vida, como influenciará, ou como normatizará o que vai ser feito e descrito no plano cognitivo, sentimental e moral.

Um aspecto importante desta contextualização, pela antropologia e pela pedagogia, é a noção de curiosidade e o amor-de-si como expressão desta necessidade de se autossustentar, de bastar-se a si mesmo, de cuidar de si, ao mesmo tempo que projeta o sujeito para fora, identifica na objetividade externa ao eu individual o campo da satisfação destas necessidades que, pela primeira vez, perdem terreno para o maior desenvolvimento relativo da força. Essa desproporção entre força e necessidade, desequilibra a balança da natureza, em favor do sujeito, com as faculdades ainda incipientes, para superar as necessidades numerosamente limitadas. Por conta desse desequilíbrio, em favor da força, Rousseau aponta a modificação da noção de tempo, e a propensão ao desenvolvimento espiritual e existencial humano por conta de uma sensibilidade e de uma subjetividade mais complexa, pela atividade e pelo conhecimento decorrente do saber sensível que se realiza efetivamente. Nesse plano, encontramos as discussões em torno da justificativa para o aprendizado das ciências e das artes, por intermédio da criação do objeto do saber e da ciência pelo objeto do saber.

De onde surge a fraqueza do homem? Esta é a questão com a qual Rousseau inaugura o livro III do Emílio. Posto que um tanto banal e repetitiva, a questão assim colocada para iniciar as reflexões sobre o desenvolvimento do homem não soa cansativa porque é justamente a desproporcionalidade, antropologicamente prevista, entre força e necessidade, binômio "categorial" que atravessa a reflexão de Rousseau em sua obra como um todo, que precisa ser evocada aqui mais uma vez. Isto se dá porque na idade próxima da adolescência, sem as aquisições da sexualidade que se avizinham, as forças humanamente dispostas desenvolvem-se, aumentam qualitativamente, mais rapidamente, do que as necessidades ainda incipientes limitadas às coisas possam superar. Quando nenhuma necessidade imaginária, nenhuma necessidade de expressão social corre o risco de atormentar a vida da criança, "os desejos não vão mais longe do que os braços". Nessas condições, a força relativa é maior, relativa em relação ao seu par, as carências, porque acham-se excedentes de força que empurram o indivíduo com sua subjetividade para fora do $e u$, que antes apenas fechava-se para conhecer aquilo que a sensibilidade imediatista podia fornecer, como fonte de conhecimento das aparências objetivas para um sujeito isolado e atomizados no eterno aqui e 
agora de sua "certeza sensível". Talvez seja por isso que não se pode falar em força apenas no diapasão da força fisicamente determinada, porque a ela são associadas as capacidades da mediação intelectiva que levam o indivíduo a se movimentar e a se colocar em marcha pelos instrumentos da intencionalidade e da subjetividade criadora. Há, segundo o genebrino, um desvio [que] é o efeito do progresso de nossas forças e do pendor de nosso espírito. No estado de fraqueza e de insuficiência o cuidado de nos conservar nos concentra dentro de nós mesmos, já no estado de potência e de força o desejo de estender nosso ser nos leva além e faz com que nos lancemos tão longe quanto possível: mas como o mundo intelectual nos é ainda desconhecido, nosso pensamento não vai mais longe que nossos olhos e nosso entendimento estende-se apenas com o espaço que mede. (ROUSSEAU, 1969, v. 4, p. 430)

Com este "excedente" de forças e faculdades relativas, verifica-se, como se fosse, uma duplicação ou uma complexificação da noção de autossuficiência a que se deve realizar e respeitar na antropologia, por conta da simples projeção para o futuro temporal, que culminará no homem adulto, o supérfluo do presente da criança em atividade produtora. Percebe-se isso porque aqui Rousseau teria cuidado de promover a educação de uma criança robusta, que tornará a vida do homem socialmente enfraquecido menos problemática, por conta da relativa tranquilidade, que as atividades e os trabalhos proveitosos e úteis poderão proporcionar. O homem social enfraquecido ficaria menos prejudicado, menos desconfortável com a situação da partilha social porque ele poderá fazer o que deve, porque ele sabe o que pode fazer para se manter. Dessa feita, verificaremos toda uma sorte de conhecimentos sensíveis sendo produzidos para contribuir com o bem-estar do indivíduo que, além do mais, é pautado pela lei de necessidade e pela autossuficiência essencial ao homem que se confirma pela atividade laboral artificiosa.

Rousseau entende que esse desejo inato de bem-estar [amor-de-si] e a dificuldade de plenamente dar conta desse desejo nos levaria a procurar novas formas de satisfação de necessidades. Segundo o autor, então, existiria uma inclinação à curiosidade naturalmente determinada, haja vista a proporcionalidade entre as paixões relativas às carências e as luzes do espírito humano, que se diferenciaria de sobremaneira da curiosidade fruto da opinião. Curiosamente, em outro momento, Rousseau refletia sobre a ocupação humana com os dados imediatamente observados. Nesse momento o cuidado dá-se por meio do uso destas sensações a se diferenciarem dos objetos intelectuais fruto da especulação. Segundo o pensador, os objetos do espírito devem ser efeitos, resultantes das operações colocas em ação pelo uso dos sentidos em sua dimensão produtora, porque afinal "a criança que lê não pensa, só lê, não se instrui, aprende palavras". O aluno então deverá ser estimulado a ficar atento aos 
fenômenos naturais apenas, como eles ocorrem, sem a tradução simbólica mediada intelectualmente, ou linguisticamente, como acontecem nos livros de escola. A satisfação da curiosidade que nasce das necessidades e paixões associadas deve ser suficiente para levar o aluno a desenvolver um saber que se pronuncia pela resolução de questões, frutos de problemas de ordem prático-objetiva.

O homem nessa fase acha-se convidado a resolver questões que ele mesmo se pôs, porque ele mesmo foi capaz de perceber as coisas, dadas as circunstâncias concretas sobre as quais ele foi posicionado. Dessa forma, o aluno não aprende a ciência, cria-a, inventa-a, tanto o pensamento, quanto seu objeto específico. "Quereis, [professor] ensinar geografia a essa criança e lhe ofereceis globos, esferas, mapas: quantas máquinas! Por que todas estas representações? Por que não começais por lhe mostrar o próprio objeto, de modo que ele saiba ao menos do que estais a falar"? (ROUSSEAU, 1969, v. 4, p. 430). Por este modelo Rousseau processa o ensino das ciências quando o sujeito da aprendizagem se põe como agente de seu próprio saber5, não como paciente, quando produz a informação porque foi capaz, antes, de encontrar o objeto do saber e o problema a ele relativo.

Com esse programa de "ensino-aprendizagem", Rousseau procura preservar a autoridade da razão, em detrimento da razão da autoridade, que seria fruto da opinião alheia que interferiria na fundamental preservação dos elementos caros à sua antropologia, ou seja, a espontaneidade das ações individuais e o rechaço ao constrangimento externo, como outro termo da ausência da liberdade que se tem essencialmente postulada. Tendo isso em vista, o saber, nas etapas e condições específicas preservadas, e a utilidade como condicionante da busca deste saber, Rousseau mantém, ao nosso ver, seu projeto de reforma social por meio do significado que tem as ciências e as artes, há muito sugerido pelo texto de 1750. Com isso, a irmandade entre uma terminologia gnosiológica e axiológica fica mantida porque o genebrino nunca pode recusar a função que os saberes de modo geral têm de desempenhar no solo socio-histórico sobre os quais os homens aperfeiçoam-se e distanciam-se, um pouco, de sua inevitável miséria.

\footnotetext{
5 "Transformemos nossas sensações em ideias, mas não saltemos imediatamente dos objetos sensíveis aos objetos intelectuais. É pelos primeiros que devemos chegar aos outros. Nas primeiras operações do espírito que os sentidos sejam nossos guias: nenhum livro além do livro do mundo, nenhuma outra instrução a não ser a dos fatos. (...) Tornai vosso aluno atento aos fenômenos da natureza e logo ele se tornará curioso, mas para nutrir sua curiosidade não apresseis jamais em satisfazê-la. Colocai questões ao seu alcance e deixai que ele as resolva. Que ele não saiba nada porque vós disseste a ele, mas porque ele mesmo compreendeu: que ele não aprenda a ciência, que a invente. Se sempre vós substituís em seu espírito a razão pela autoridade, ele não raciocinará mais, ele não será mais do que joguete da opinião dos outros” (ROUSSEAU, 1969, v. 4, p. 430).
} 
O conhecimento sensível, portanto, mantém-se, mas organizado a partir de outras bases, não mais como aquele saber relativo a um sujeito que pouco se movimenta porque carece da força suficiente para ativar suas faculdades. Por ora, o saber sensível realiza-se porque a força propicia, no plano físico por exemplo, as condições corpóreas favoráveis para o movimento amplo dos órgãos do saber sensível, e no plano subjetivo, as mediações que farão a força efetivar-se como categoria para a diferenciação típica do homem agente de sua história, porque o homem põe seu eu fora dos limites da atomização e de um solipsismo. Segundo Vargas, há que se "compreender que o nascimento das ciências implica uma dupla aproximação: uma aproximação antropológica que explica as motivações humanas do ato de conhecimento elaborado e uma gnosiológica que explica os mecanismos que tornam um tal conhecimento possível. Do ponto de vista antropológico, a ciência é uma utilidade" (VARGAS, 1995 p. 88). Quer dizer, que os poucos saberes que importam à nossa limitada inteligência devem se pautar pela contribuição ao bemestar, os únicos dignos das pesquisas de um homem sábio e de uma criança que prepara-se para a sabedoria, como havia sugerido o genebrino desde o lançamento de seu $1^{o}$ Discurso, no qual não tratava mais de procurar saber das coisas existentes por elas mesmas, mas das coisas orientadas pelo signo da utilidade. Abandona-se a filosofia de gabinete para voltar o aluno à experiência inspirada nos trabalhos dos jovens não policiados e que vivem do que os campos cultivados e os ofícios associados a isso podem oferecer. A utilidade então tende, respeitosamente, a preparar o plano espiritual e concreto para que o homem que surgirá da infância produtiva seja capaz de reconhecer o que é bom e conveniente na sociedade e na educação dos homens.

Para esse programa, Rousseau sugere, na terminologia da educação negativa, a preservação do erro: por um lado, pela não introdução do signo linguístico, porque este seria responsável pela absorção da atenção que a criança pode depositar sobre as quais se atém; por outro lado, pelo fato de que a representação linguística na idade em que ela não deveria ser acionada primordialmente, o aluno perca o propósito da criação de seus objetos de saber e da ciência a eles associada. Não importa, no caso em questão, o acúmulo de saberes, de informações, mas que as ideias sejam claras e justas. A ignorância, portanto, não deve ter tanta importância aqui, se ela vier acompanhada pela ausência do erro, por mais que, aparentemente, uma educação profícua em conteúdos de saber possa ser, num primeiro momento, mais interessante e atraente. Nessa acepção de educação proposta por Rousseau, em que a negatividade funcionaria, nesse contexto, como filtro para o conjunto das idealidades relativas à socialização, traz consigo uma dimensão passional para o aprendizado das 
ciências, se este desejo de saber for compatível com o nível psíquico e físico do educando e se os métodos de seu ensino souberem provocar sentimentos de apreço pelo saber. Afinal,

eis o tempo também, diz Rousseau, de acostumá-lo pouco a pouco a prestar atenção contínua ao mesmo objeto, mas nunca como obrigação, é sempre o prazer ou o desejo que deve produzir a atenção, pois é preciso grande cuidado que ela não o canse e que não o aborreça. Tenhais, então, sempre os olhos abertos e, caso aconteça algo, abandonai tudo antes que ele se perturbe, porque não importa que ele aprenda desde que não faça nada malgrado seu. (ROUSSEAU 1969 v. 4, p. 436).

A partir então desta presença constante do objeto ante o sujeito, é pressuposta, por seu turno, tanto a reiteração experimental, quanto a qualificação desta experiência pela atenção a partir da qual são estimuladas as intenções como "princípio" a definir a utilidade da coisa como objeto de aprendizado. Isso acontece no intuito de estimular a espontaneidade de quem aprende, em detrimento da obrigação, outra expressão do constrangimento atribuído pelo genebrino, ao nosso ver, ao plano social.

Podemos entender, de acordo com as palavras de Rousseau, que o desejo de saber é um estimulante ao advento das ciências, das artes e o mundo da cultura de um modo geral, porque esse elemento passional existe como efeito de uma ausência, de uma incompletude, de uma falta, do encontro das circunstâncias objetivas externas e o constrangimento natural e sua capacidade de modificação e aperfeiçoamento. Dizer que o homem em geral e o aluno deste tratado de educação em particular, sujeito em desenvolvimento para uma história do gênero humano, sentem um desejo de saber significa admitir uma posição realista sobre o fato, segundo o qual o homem precisa conhecer porque efetivamente padece e, ao ser consciente deste padecimento, realiza algo. $\mathrm{O}$ homem produz algo para compreender e solucionar os dramas das incompletudes impostos pelos limites externos, que a existência humana enfrenta, efetivamente, concretamente, no devir histórico que pode, de um lado, resultar no enfraquecimento do indivíduo porque o torna dependente das novas necessidades resultantes de suas criações e de outros indivíduos, mas, por outro lado, pode fortalecer o gênero humano porque perpetua na memória as conquistas socialmente estabelecidas. Como a ausência impõe-se ao homem, a perfectibilidade, pressuposta como princípio da criação e da história, aciona faculdades, capacidades que estavam em potência, mas que precisavam ser efetivadas pelas circunstâncias objetivas determinantes.

A partir de então, esse desejo de saber como estimulante ao desenvolvimento dos saberes em geral teria de obedecer (para ser bom e 
eficiente) e respeitar a regra que a utilidade indica. Ao nosso ver, isso tem relevância, já que o fato de coisas serem conhecidas, produzidas com a finalidade de prestarem-se ao serviço de conferir a força ao homem pela solução de problemas e limitações que o enfraqueceriam, porque: i) em primeiro lugar, a utilidade pode fornecer ao desejo de saber uma qualificação positiva axiologicamente à ação em busca da informação, no sentido de colocar as coisas como "critério" de justiça para a informação, que não deslocou-se de sua função, a de "solucionar" as limitações resultantes da relação prático-objetiva do indivíduo com a realidade que o cerca. Pensando nesses termos, é como se o sujeito que deseja um saber preenchesse sua interioridade com o objeto do saber e não com seu $e u$, hipertrofiado pelo desejo de estima, pela vaidade de dominar o conteúdo de um saber6. A regra da utilidade aqui visa substituir a noção de que a ciência nasceria de uma subjetividade que coloca a ciência e o objeto do saber em segundo plano porque preencheu a si mesmo com seu eu que tornou-se objeto de desejo para si mesmo, pela coisa útil, pelo saber que pode servir a muitos outros eus, quando o saber assume mais a função de melhorar a vida da realidade social sobre a qual se estabelece; ii) em segundo lugar, o saber torna-se, portanto, moralmente associado, ou qualificado porque colocou-se como condição, como meio e não como fim em si mesmo, para a transformação justa da vida dos indivíduos em sociedade.

Quando tomamos este tema da utilidade e o associamos às preocupações sociais e políticas, percebemos que, embora toquem em problemas comuns, um certo distanciamento entre pensadores como Rousseau e Helvetius 7 aparece, mesmo na época em que esse debate

6 "Com efeito, quer folheando os anais do mundo, quer suprimindo crônicas incertas com pesquisas filosóficas incertas, não encontraremos nos conhecimentos humanos uma origem que corresponda à ideia de que se gosta formar a seu respeito. A astronomia nasceu da superstição; a eloquência da ambição, do ódio, da lisonja, da mentira; a geometria da avareza; a física de uma vã curiosidade; todas, e a moral inclusive, do orgulho humano. As ciências e as artes devem, então, seu nascimento aos nossos vícios: nos encontraríamos menos em dúvida quanto às suas vantagens se a devessem a nossas virtudes" (ROUSSEAU, 1964, v. 3, p. 17).

7 Maruyama sugere que a relação teórica dos dois autores é marcada por semelhanças, por certa comunidade "sobretudo nas concepções gerais a respeito da relação entre moral e política. Para um como para o outro, só podemos conhecer os princípios que devem regrar a vida política, a legislação, o governo dos povos, a partir do conhecimento do que o homem é e, mais particularmente, dos motivos e princípios que fazem agir. (...) Para os nossos dois filósofos, é somente conhecendo os princípios da moral, as regras oriundas da razão, das paixões e dos sentimentos dos homens, que podemos alcançar os princípios de sua vida política e o melhor modo de conduzi-los" (MARUYAMA, 2005, p. 401). Ao nosso ver, por outro lado, retirando estes aspectos gerais, nas minúcias, com os pressupostos e os fundamentos, os autores diferenciam-se fortemente. Dentre as diferenças, de acordo com a política de Helvetius, a ênfase não deve ser colocada sobre os sujeitos, mas sobre as ações humanas concretas, ênfase que não pode resultar nunca na hipótese do estado de natureza, tão pouco no contrato social. O Público de Helvetius julga, portanto, não as 
ocorria efetivamente, independentemente da constatação que os intérpretes identificam para o caso em questão. Sobre esse último pensador sobram iniciativas de teorizar o interesse, a utilidade e como, em geral, uma sociedade pode ser organizada, tendo como pressuposto a redução simplificadora de toda uma antropologia que se baseie na sensação como fonte de conhecimento, e nos prazeres e dores como motores de toda e qualquer ação humana. Há intérpretes que chegam a sugerir que na ética de Helvetius o único valor é a utilidade pública medida pela presença de prazer ou ausência de dor, como se o bem individual fosse, por sua vez, a tradução do prazer individual. Além disso, a força das paixões, os desejos, seriam determinantes pela procura de conhecimento, de tal forma, salienta Grossman, que "se nós desejamos ter homens que estão alertas à procura por verdades adicionais devemos fortalecer o amor por prazer do qual são distintas as várias paixões" (GROSSMAN, 2008. p. 128). Segundo o próprio Helvetius, "é a emulação que produz os gênios, e é o desejo de se ilustrar que cria os talentos. É no momento em que o amor à glória se faz sentir no homem e se desenvolve nele que podemos datar o progresso de seu espírito. Eu pensei sempre sobre ela, a Ciência da educação pode ser somente a ciência dos meios de excitar a emulação" (HELVETIUS, 1989, p. 68). Helvetius ainda salienta que as paixões

seriam desejos vivos: estes desejos podem ser igualmente conforme ou contrário ao bem público. Se a avareza e a intolerância são paixões nocivas e criminais, de outra forma há o desejo de se ilustrar pelos talentos e pelas virtudes patrióticas. Anulando os desejos, anulamos a alma, e qualquer homem sem paixões não tem nada nele, nem o princípio de ação, nem o motivo para se mover. (HELVETIUS, 1989, p. 85)

Isso significa que ao destruir as paixões dos homens destrói-se, com isso, a possibilidade de ações existirem.

Ao nosso ver, esse relevo dado às paixões e como elas contribuem, de qualquer forma, para o desenvolvimento dos saberes é o que poderia incomodar o genebrino, neste aspecto da querela com Helvetius. Vimos todo um cuidado ao longo do $1^{\circ}$ Discurso de desmistificar a determinação necessária entre desenvolvimento artístico-científico e progresso humano e Helvetius, justamente, vai promover a vaidade e o desejo de glória como um dos motores imprescindíveis do progresso intelectual humano. Rousseau, quanto a isso concordaria com a constatação da decrepitude moral dos tempos contemporâneos, não sem o travo da língua a partir do qual ele elaboraria um plano de reforma da ciência e de seu advento, tendo em vista as intenções de quem a pratica, regulando-as no momento mesmo em que as paixões e os efeitos das ausências objetivas são percebidos. Não

intenções de quem pratica uma ação, como poderia ser verificado em Rousseau, mas as ações objetivamente realizadas, segundo o resultado social a que se chegou com elas. 
por isso, entendemos que Helvetius assine um cheque em branco para as atitudes dos homens quando sentem algo. Ao nosso ver, esse pensador precisa da avaliação a posteriori, de uma sociedade já existente e já regulada por uma legislação, para ter a real dimensão da paixão, do seu uso, do que ela promove, dos seus resultados práticos, como se o interesse social fosse condição para definir o valor de um conhecimento e das paixões sentidas em nome desse conhecimento. Por seu turno, Rousseau afirma, como vimos, que as paixões nos levam ao conhecimento, mas não é qualquer paixão, nem qualquer finalidade posta pelos saberes, determinada em grande medida pela sociedade dos intelectuais, que devem ser desejadas. Num outro sentido, no estágio em que a digressão sobre os níveis de saber e as finalidades são colocadas no Emílio, por exemplo, bem como pelo modo em que ocorreram na hipótese do estado de natureza forjada no $2^{O}$ Discurso, nos encontramos num campo de atuação, e de desenvolvimento intelectual previsto pela antropologia, na qual a intersubjetividade ainda não se acha quando as coisas e a manutenção vital são os reais motivos das ações e da criação das artes.

Com Helvetius, se a glória e as paixões têm esse papel superlativo e a competição é estimulada, há então, sempre o pressuposto de uma individualidade com a qual os sentimentos de alguém e suas paixões são colocadas a prova e são comparadas como forma de medida do saber e do poder. O palco da sociabilidade já está montado sobre o qual os saberes são estimulados sempre tendo o outro como pressuposto para seu desenvolvimento. Epistemologicamente, isso se justifica porque se Helvetius reduz todas as atividades subjetivas à sensação, a capacidade de comparar e estabelecer juízos - que só tardiamente são alcançadas pelo homem rousseauísta - são apresentadas como alteração ou diferenciação da sensação, como a expressão de uma solidariedade entre o conteúdo do saber e a função lógica de pensamento. Essa fundamentação epistemológica fica coerente com as informações decorrentes das relações sociais já entendidas como condição e critério de avaliação axiológica, inclusive, dos saberes humanos.

No momento, não desdobraremos os detalhes do debate entre esses autores e como seus pensamentos se posicionariam no período, porque esse confronto, acreditamos, ficará mais evidente quando Rousseau for estabelecer seus pressupostos epistemológicos ao final do livro III do Emílio, sobre os quais ainda nos debruçaremos. Valeu-nos esse pequeno desvio comparativo para mostrar certa especificidade do pensamento de Rousseau nessa matéria, uma vez que concorrem para o desenvolvimento de questões epistemológicas aspectos de sua antropologia, que se mostra, em certa medida, normativa. A partir desses fatores, elabora alguma idealização do processo de constituição do saber, de como os homens 
deveriam conhecer e de que forma esse saber deve se processar, sem o recurso à intersubjetividade na etapa infantil do desenvolvimento humano por exemplo, para atingir o objetivo de sê-lo, acima de tudo, socialmente e moralmente relevante.

Tendo em vista o que foi exposto, o ser humano que aprende nesse nível, ainda se encontra isolado, dissociado do pleno convívio social para o qual ele está sendo preparado, cujos problemas e limitações à efetivação de seu ser são inevitáveis, futuramente na idade adulta, em que a fraqueza humana torna-se absoluta e irreversível. Segundo esses procedimentos educativos, a figura do preceptor ganha relevo porque ele precisa de uma habilidade singular para, dentre outras coisas, ser capaz de traduzir o pensamento incipiente do aluno, já que ele não pode se pautar por aquilo que as palavras dizem na sua literalidade. "É preciso, diz Rousseau, observar menos as palavras que ele pronuncia do que o motivo que o leva a falar. Esta advertência até aqui menos necessária, passa a ser a mais importante tão logo a criança comece a raciocinar" (ROUSSEAU, 1969. v. 4, p. 436). O preceptor deve ser atento aos motivos, às intenções, ao que o aluno quis dizer e que não foi capaz de dizer, porque lhe faltavam as habilidades espirituais para isso. Ao preceptor cabe a habilidade, portanto, de ver e traduzir não o discurso, mas as ações e as intenções, como se fossem os selos de acordo com os quais o valor das ações passa a estampar.

Isso é sugerido na perspectiva de que a educação deve ter um valor, determinado pela autonomia de quem pensa, por um lado, que deve ser educado para que o pensamento, por mais simplista, seja proferido como realização independente, sem constrangimento e sem atribuições. Esses constrangimentos, em geral, revelariam o modus operandi da "educação tradicional", contra a qual o genebrino se pronuncia e sobre a qual pesam essas obrigações como outro modo de entendermos as antecipações pedagógicas como pré-maturações. Contra essa metodologia de ensino, os objetos, as coisas, os fatos devem falar mais do que os signos e suas representações convencionais, das quais este aluno deveria distanciar-se. Por outro lado, se a fala for utilizada, se ela for acionada, o critério de sua expressão, neste contexto, tende a ser mais a objetividade com a qual o aluno se relaciona, do que abstrações e generalizações. Se é no terreno do ação que a expressão do aluno ganha sentido, as intenções no ponto de vista da subjetividade são importantes a serem observadas, porque são por intermédio delas que o indivíduo põe em marcha as teleologias que foi capaz de verificar e de produzir nas relações diretas estabelecidas efetivamente, tais como as finalidade relativas no plano do trabalho. Dito de outro modo, as intenções têm papel central aqui porque elas revelam as conquistas já adquiridas de uma interioridade em transformação, em processo de complexificação, porque seriam de um lado o reflexo das 
influências objetivas que obrigam o indivíduo a se movimentar, e por outro lado, definem o plano de ação, de um sujeito responsável por si mesmo, cujas realizações se concretizariam no a posteriori da ação realizada, com o objetivo alcançado. Quer dizer,

ao invés de colar uma criança aos livros, se eu a ocupo em uma oficina suas mãos trabalham em proveito do espírito; torna-se filósofa e crê ser apenas uma operária. (ROUSSEAU, 1969, v. 4, p. 443).

À medida que a criança avança na inteligência, outras considerações importantes nos obrigam-nos a escolher melhor sua ocupação. Tão logo ela chegue a conhecer-se bastante a si mesma para perceber em que consiste seu bem-estar, tão logo ela possa alcançar relações tão amplas para julgar o que lhe convém e o que não lhe convém, a partir de então ela está em condições de sentir a diferença entre o trabalho e o divertimento e de observar este aqui como descanso do outro. Então os objetos de real utilidade podem entrar em seus estudos e levá-la a dar-lhes uma explicação mais constante do que dariam as simples diversões. (ROUSSEAU, 1969, v. 4, p. 444)

Esse trecho parece confirmar o que imaginamos porque existe, textualmente, de um lado, as etapas descritas de conhecimento e de aprendizado: da relação da criança consigo mesma, e a etapa da relação da criança com aquilo que a cerca e que daria conta do cuidado de si mesma. Nesse contexto, cognitivamente, a criança tem de perceber as coisas físicas, materialmente apresentadas, sem que nada das relações de apreço e de valor sejam atribuídas por quem quer que seja na sua relação dos objetos. O chamado bem-estar poderia ser nada mais do que o não sofrer, condição que seria expressão de um homem de natureza que busca a satisfação de suas necessidades, as mais elementares, sem o selo da vaidade e da vontade corrompida pela mediação comparativa do valor e da moralidade.

Então, à criança é ensinada a arte de prevenir, de prever o sofrimento que há de vir, de ter o que gozar para manter sua integridade física, etapa a mais essencial, sem a qual a moralidade nem seria possível. Poder-se-ia dizer que seria este o desiderato do contrato? O que pretende garantir o contrato como elemento sem o qual a adesão dos indivíduos seria impossível? De modo essencial, o contrato garante a segurança daqueles que entram em relação político-moral. É sabido que aqui Rousseau não tematiza o homem moral, nesta altura do texto, mas lança as bases sem as quais a moralidade não se instala, porque o homem sem saber o que de fato importa, não saberia sequer perceber o real valor das coisas e de sua vida. $O$ genebrino entende que

quando, antes de sentir suas necessidades, eles as preveem que sua inteligência está já muito desenvolvida e começam a compreender o valor do tempo. É importante, então, acostumá- 
las [as necessidades] a dirigir seus empregos sobre os objetos úteis, mas de uma utilidade sensível para sua idade e relativa às suas inteligências. Tudo o que se tem da ordem moral e os usos da sociedade não devem, tão cedo, lhe ser apresentado, porque não está em condições de entendê-lo. Trata-se de uma inépcia exigir delas que se apliquem a coisas que dizemos vagamente ser para o bem delas sem que eles saibam qual é este bem, das quais lhes asseguramos que tirarão proveito quando forem grandes sem que eles tenham agora qualquer interesse por este proveito que eles não saberiam compreender. (ROUSSEAU, 1969, v. 4, p. 444)

Com isso, sem a noção da utilidade que tem a autopreservação não poderia medir seu interesse, nem torná-lo objetivo suficiente para levá-lo, em certo aspecto, a ser o motivo ${ }^{8}$ das adesões individuais na sociedade contratual. Parece-nos imprescindível o recurso a essa noção de utilidade real, orientada por um conhecimento das coisas, porque elas dariam a noção das condições materiais e existenciais dos indivíduos sem as quais os deveres, que demandam a intersubjetividade, não poderiam se expressar e dar a conhecer o que é devido a cada um, no que se refere, por exemplo, ao tema da propriedade legítima como expressão do trabalho.

À criança em desenvolvimento, que deve se tornar um adulto, as ideias do "homem feito" podem servir para sua instrução, mas essas ideias à criança não estão presentes, nem devem ser apresentadas, como se ela tivesse de ser colocada numa condição de ignorância completa a respeito da intersubjetividade adulta, uma vez que o verdadeiro livro, "os verdadeiros mestres" são, para esse momento, a experiência sensível e os sentimentos e a ideia relativa à sua idade, com a qual o projeto educacional assegura a proporcionalidade a se estabelecer entre fase de desenvolvimento, objetividade e capacidade espiritual de compreensão. Ao nosso ver, essa regulação do desenvolvimento do homem, essas regras de administração, segundo as quais aquilo que pode ser feito deve corresponder àquilo que pode ser apreendido, portanto em relação às capacidades físicas e espirituais, seriam sinais da existência de uma normatividade para cuidar dos valores que as intenções terão de ganhar quando condicionarem as ações.

Esse "etapismo" educacional, por sua vez, mostra uma ordem, uma regra, uma regulação para que a natureza possa expressar no homem suas condições as quais servirão de modelo para o homem que há de vir. Rousseau parece, à primeira vista, considerar essas etapas como interdependentes e relacionadas, uma se sucedendo à outra numa ordem lógica, física e sentimental, embora elas precisem ainda de uma certa independência para que garantam a preservação dos objetivos educativos e

8 Cf. Sobre este aspecto, dos interesses serem o motivo da associação, observar: DERATHÉ, Rousseau et la science politique de son temps, pp. 232-41. 
a coerência com o ordenamento previsto pela natureza. Desse modo, sujeito ao curso da história, para esse homem estão previstas modificações, que fazem dele um ser de uma natureza aberta às diferenciações circunstanciais. Pensando dessa forma, a diferença na fundamentação social e política encaminhada por Rousseau não pode esperar as ações acontecerem para que, a posteriori, as sociedades já existentes, com seu positivismo legiferante, faça a difícil tarefa de correção dos homens. A regulação vem acontecendo desde o nascimento do indivíduo, passando por etapas, como essa na qual se encontra o Emílio pré-adolescente, em que as atividades devem ser relativas àquilo que o indivíduo pode pensar porque soube fazer.

Não sem sentido, no livro III do Emílio o genebrino dedica-se ao saber oriundo da prática e das experiências sensíveis, como condição para o estudo e desenvolvimento da ciência para o sujeito de aprendizagem, alheio aos manuais cujas lições tratam mais da forma dogmática e constrangedora de ensino das ciências. Nesse sentido o exemplo de uma lição de astronomia ou geografia experimental é sugerido. O aluno é levado a solucionar o seguinte problema: como chegar a Montmorency, partindo do campo, com as informações espaciais disponíveis? Em primeiro lugar, Rousseau parece indicar que o aluno estaria sendo levado a realizar uma atividade prática por meio de conceitos e objetos de estudo científicos sem o peso da "linguagem científica", da qual o aluno não tem condições de extrair sentido. Por sua vez, se o ensino fosse transmitido o aluno, passivamente, receberia a informação sem ter dimensão objetiva de seus conteúdos, ao passo que nesse exemplo Emílio é convidado a resolver uma questão, pautada pela necessidade de conservação, a partir da qual a utilidade ganha realidade, a meta é estabelecida, e é a condição necessária para esta etapa de formação, sobre a qual o aluno formulará um juízo oriundo da prática, conduzido pelo preceptor. O preceptor por outro lado não comanda as ações, mas pergunta, supondo um conhecimento do aluno, adquirido por experiência, da direção a ser tomada. Diante desse quadro, o que verificamos é a ideia de que as coisas, se bem apreendidas, se bem experimentadas, podem ser elas mesmas fontes de informação segura para a solução de qualquer problema que o homem possa se colocar. A relação do homem com as coisas, com isso, deveria ser bem conduzida para que o produto desta relação seja repleto de informações livres de pré-noções, porque o conteúdo é obtido não por uma utilidade abstrata escrita no livro que disse ser a geografia importante por ser a ciência do espaço, mas porque a geografia está fincada com seus pés na realidade objetiva e no espaço, no qual o homem se encontra e a partir do qual ele é responsável por produzir suas necessidades e encontrar suas satisfações. 
No contexto dessa lição, a partir dele, a figura do preceptor merece consideração: ao mesmo tempo em que ele realiza o trabalho de produzir um artifício, um homem que seja racional, que saiba produzir e realizar as necessidades que não se encontram no estado de natureza, e ainda que seja responsável por realizar o ideal de uma educação que respeita a natureza. As lições propostas, então, devem preservar a espontaneidade, ou o não constrangimento, o cultivo e manutenção da força, quando conduz uma atividade controlada, cercada de um jogo de perguntas e respostas, que leva o aluno a dar as respostas para uma solução prática com os conteúdos e objetos das ciências teóricas. Quando Emílio fica excitado com as descobertas entende que "a astronomia serve para alguma coisa". E o preceptor quer fazer notar

que, se ele não disser essa última frase, ele a pensará. Pouco importa, contanto que não seja eu quem a diga. Ora, podeis ter certeza de que não esquecerá por toda a vida a lição desse dia, ao passo que, se eu só lhe tivesse feito supor tudo isso em seu quarto, meu discurso teria sido esquecido no dia seguinte. Devemos falar tanto quanto possível através das ações, e só dizer aquilo que não podemos fazer. O leitor não espera que eu o despreze tanto que lhe dê um exemplo de cada espécie de estudo; no entanto qualquer que seja a questão, nunca é demais exortar o preceptor a fazer com que sua prova seja proporcional à capacidade do aluno, pois, mais uma vez, o mal não está em que ele não entenda, mas no que ele acredita entender. (ROUSSEAU, 1969, v. 4, pp. 450-1)

O preceptor revela, da parte de Rousseau, uma "dialética" entre natureza e cultura em que a lição promove o artifício, a transformação de um homem para a sociedade inexistente no estado de natureza, que se altera e desenvolve-se como ser racional, mas ao mesmo tempo mantém as espontaneidades e liberdades como a expressão da natureza humana. Não sem razão diz Vargas ser a pedagogia de Rousseau um laboratório, no qual os experimentos, condições artificiais de exame, são criados para ver e rever a natureza desenvolver-se numa condição em que as intempéries ${ }^{9}$ não se acham a ponto de transformar o indivíduo em algo tão desfigurado como a estátua de Glauco pode exemplificar. Dessa maneira, o preceptor realiza o artifício, a partir de um procedimento artificial, para preservar a espontaneidade natural. A educação boa, então, será aquela que souber equacionar o aspecto inevitável de qualquer processo educacional, a

\footnotetext{
9 A educação rousseauísta, nas palavras do intérprete, "é uma sorte de artifício protetor, que tem por outro objetivo exclusivo a alcançar a essência de uma coisa fora de sua existência factual, que se chama de laboratório". "Rousseau chama educação uma espécie de crescimento espontâneo, de preenchimento de uma vacuidade original (...). A educação se deduz então de uma simples subtração, o homem menos a criança é igual à educação e o resultado consiste em três coisas: a força, o julgamento, e a assistência." (VARGAS, 1995, pp. 9-10)
} 
mudança e a alteração, sem transformar o homem num ser inteiramente outro, preservando a espontaneidade, a liberdade da condição essencial que não deve se modificar.

De acordo com a lição de astronomia e geografia experimental, os juízos puderam ser evocados, por sua vez, por artes socialmente determinadas porque, em seu modo de operação a partir da imagem utilizada acima como expressão da construção teórica de Rousseau, essas artes buscam o respeito à noção de utilidade das coisas como condição para a manutenção da vida, em detrimento das artes que simulam as aparências, aspecto que Rousseau quer evitar a todo custo aqui. Para isso, Rousseau ainda não vê noções de arte e de trabalho em termos intersubjetivos, pois as coisas e não os sujeitos são os reais princípios das ações e das relações entre os indivíduos. É como se as coisas e a utilidade posta por elas fossem suficientes para o tipo de educação que se tem aqui, para o tipo de interioridade a se esperar de um homem nessa fase da vida pessoal e da história social, que se prepara para o enfrentamento da sociabilidade em termos morais.

O homem que temos em mão é um indivíduo que julga os corpos da natureza pela relação da sensibilidade com a utilidade, a partir da qual pode garantir seu bem-estar e a possibilidade de sua conservação, julgamento que atinge ainda quaisquer formas de trabalho. Rousseau educa Emílio e resgata Robinson Crusóe. O único livro que deveria ser usado por Emílio no momento seria aquele romance que ensina como ser homem, livremente, pela autoconservação, pelo cultivo do trabalho e de artes essenciais (agricultura) e Crusoé, portanto, realiza-se como a personagem modelo da sua "educação natural". Diz Rousseau,

sem o amparo de seus semelhantes e de instrumentos de todas as artes, provendo sua subsistência, sua conservação, e procurando ainda um tipo de bem-estar, eis um assunto interessante para todas as idades (...). Eis como realizamos a ilha deserta que me servia de comparação. Este estado não é, admito, aquele do homem social, verdadeiramente não deve ser aquele do Emílio, mas é por meio deste mesmo estado que ele deve apreciar todos os outros. O meio mais seguro de se elevar acima dos preconceitos e de se ordenar os juízos sobre as verdadeiras relações das coisas é colocar-se no lugar de um homem isolado e de julgar tudo como este homem deve julgar, com relação à sua própria utilidade. (ROUSSEAU, 1969, v. 4, p. 455.)

Nas palavras de Rousseau, então, não estão presentes, num certo aspecto, as lições morais da sociabilidade ordinária, para a qual prepara-se Emílio, mas as lições da indústria humana que podem estar presentes no quotidiano, de um indivíduo que seria o exemplo por excelência da capacidade de autossuficiência, o homem que, sem os vícios e corrupções 
da espiritualidade moral, é capaz de acionar tudo aquilo que a história do gênero humano acumulou em nome da necessidade de se manter vivo, isoladamente. Sem os outros, temos a imagem de alguém que pode viver bem do que realiza, pelo trabalho, do qual são extraídas mais lições de bom comportamento humano do que as lições livrescas dos manuais de moralidade.

Nesse caso, Rousseau vê no trabalho a realização humana "menos social", pelo aspecto de não depender da avaliação moral alheia ${ }^{10}$. Por outro lado, o trabalho como expressão do aperfeiçoamento humano seria, ao nosso ver, mais pleno de valores e exemplos mais importantes para o projeto de educar uma pessoa para ser forte, de se manter e de cultivar a integridade e a autenticidade. Existe no nosso entendimento, por mais que isso não esteja explícito, um valor moral do trabalho, ou um valor educativo do trabalho que supera o campo mesmo da moralidade com o qual identifica-se o projeto filosófico de Rousseau como um todo.

\section{Conhecimento e trabalho}

Existiria uma estima pública, em razão inversa da utilidade real das diversas artes. Com isso, a obra de Defoe traria os exemplos que precisa o indivíduo em desenvolvimento: para compreender o valor intrínseco das "artes naturais" que preservam a vida, de um lado; e de outro, prepara e fortalece o indivíduo para a dependência mútua entre os homens, mas que seja essa dependência um fato trazido pelas coisas com sua utilidade efetiva, concreta, pelo trabalho, e não a dependência que pode gerar o dano, própria do campo da moralidade. Se o real valor das coisas aqui se mede pela relação sensivelmente compreendida entre a utilidade e os trabalhos dos homens, a compreensão mesma do que seria útil realiza-se pela compreensão das coisas como garantia da autopreservação, que poderia ser ameaçada se a dependência mútua entre os homens for mostrada pelo reino do supérfluo, do qual tem-se mais a imagem da utilidade ou a aparência de utilidade real, cuja origem pode ser detectada pelo aperfeiçoamento e alteração ampla da indústria humana e suas artes inessenciais ${ }^{11}$. Algo que seja uma aparência de utilidade não pode ser

10 "Vosso maior cuidado deve ser o de afastar do espírito elevado todas as noções de relações sociais que não estão ao seu alcance, mas quando o encadeamento dos conhecimentos vos forçai a mostrar a lhe mostrar a mútua dependência dos homens, no lugar de lhe mostrar pelo lado da moral, desviai sua atenção em direção à indústria e as artes mecânicas que os tornam úteis umas as outras" (ROUSSEAU, 1969, v. 4, p. 456).

11 "Há uma estima pública associada às diferentes artes em razão inversa de sua utilidade real. Esta estima se mede diretamente pela inutilidade mesma e assim deve ser. As artes mais úteis são aquelas que ganham menos porque o número de operários é proporcional às necessidades dos homens e o trabalho necessário a todos forçosamente permanece tendo um preço que o pobre pode pagar. Ao contrário, essas pessoas importantes que não chamamos de artesãos mas de artistas, trabalhando unicamente para os ociosos e para os 
confundido com uma utilidade real, a satisfazer uma necessidade verdadeira, como autopreservação. Sobre isso Rousseau levanta os seguintes questionamentos:

O que se tornarão vossos alunos se deixardes que adotem esse tipo de preconceito, se vós próprios vos favorecerdes, se vos virem por exemplo entrar com maior consideração na loja de um ourives do que na loja de um serralheiro? Que julgamento terão do verdadeiro mérito das artes e do verdadeiro valor das coisas quando eles verão por todos os lugares o preço da fantasia em contradição com aquele preço extraído da utilidade real, e que quanto mais uma coisa custa menos ela vale? (ROUSSEAU, 1969, v. 4, p. 457).

$\mathrm{O}$ cuidado com o uso indiscriminado das artes permite verificar, portanto, um desdobramento espiritual, ou anímico do qual devem ser preservados os fatos típicos da ilusão, da imaginação, das abstrações, das aparências da qual a moralidade parece ser o terreno mais fértil de exemplos. Se tratamos de um indivíduo que deve ser concretamente educado, para um momento em que a concretude poderia ser colocada de lado, sua subjetividade teria de ser coerente com este momento cujas lições devem ser extraídas das próprias coisas, enquanto sejam elas garantias de bem-estar e não da perdição e decrepitude social que opõe os homens e suas artes, em conflito recíproco. O homem para o genebrino deve ser o último grau de conhecimento que alguém deve ter em seu processo formativo, quando, tradicionalmente é o primeiro a ser estudado. Como poderia uma criança "julgar seus próprios juízos" se não sabe antes "esclarecer seus erros"? Pois, "é um mal saber o que eles pensam quando se ignora se o que eles pensam é verdadeiro ou falso". A quem cabe educar uma criança, "ensinai-lhe primeiro o que são as coisas em si mesmas e lhe ensinareis depois o que elas são aos nossos olhos: é assim que ele saberá comparar a opinião à verdade e elevar-se acima do vulgo, porque não conhecemos os preconceitos quando os adotamos e ainda não conduzimos o povo quando nos parecemos com ele" (ROUSSEAU, 1969, v. 4, p. 458).

Vê-se, com isso, que Rousseau propõe evidentemente estabelecer um primado das coisas e de suas finalidades para a satisfação objetivas de necessidades, algo que deve determinar antes o espírito, em detrimento de concepções que colocam num puro fenomenismo as sensações, sem conectá-las com os objetos das quais são expressão, as sensações de objetos puros da percepção desconectados das reais funções que podem exercer e do real papel que podem desempenhar como fonte de superação dos obstáculos vitais. Num outro momento, o genebrino sugere, pela teleologia das coisas, uma nítida antecedência da objetividade sensível em

ricos, colocam um preço arbitrário para suas ninharias e como o mérito desses trabalhos vãos existe apenas na opinião, seu preço mesmo faz parte do mérito e são estimados proporcionalmente pelo que custam" (ROUSSEAU, 1969, v. 4, p. 457). 
relação ao espírito, ou à razão, da qual retira sua fonte de transformação e complexificação, negando o idealismo de uma razão hipostasiada, repleta dos poderes de criação. Vargas sugere que Rousseau, a partir desse destaque dado à utilidade e ao trabalho, seria qual um materialista radical porque "recusa o primado do pensado sobre a matéria", mas também o "primado da matéria sobre o pensamento" para postular o primado da "prática laboriosa sobre toda coisa, matéria e pensamento". A fonte do pensamento, do conhecimento e das transformações porque passam a subjetividade humana, é a atividade produtiva do trabalho por meio da qual a teleologia, não da matéria bruta, mas dos "materiais concretos na sua diversidade e ocorrência", determinam uma razão sensitiva e uma intelectiva segundo o incremento "das forças individuais investidas na observação utilitária" (VARGAS, 1995, p. 96). Poder-se-ia dizer que a economia rousseauísta, por sua vez, é antissubjetivista porque orienta-se pelo exercício da força que as coisas exercem sobre os homens, pela necessidade, pela técnica. Por outro lado, procede de uma vontade amparada por uma física sem intenções, da qual não se acham as intersubjetividades, e que vai orientar o surgimento do trabalho e da troca. Portanto, as necessidades e as coisas produzidas, em decorrência dessas necessidades, é que ganham primazia porque seriam elas e não a intencionalidade humana a condicionar as primeiras divisões do trabalho, e não o contrário. Parece que Rousseau guarda as intencionalidades e o espiritualismo do homem para o campo da moral, quando ela surgir. Quando for esse o momento, as coisas perdem o valor de utilidade real porque as intencionalidades serão "roubadas" para o campo da moralidade em que os valores serão condicionados por todo um plano de intenções a partir do qual as ações, desde a subjetividade e de uma causalidade interna, serão avaliadas quando acontecerem também objetivamente. Para Emílio,

no lugar das leis sociais que ele não deve conhecer, ligamo-lo às cadeias de necessidades. Ele ainda é quase um ser físico, continuemos a tratá-lo como tal. É por sua relação sensível com a utilidade, sua segurança e com sua conservação e com seu bem-estar que ele deve apreciar todos os corpos da natureza todos os trabalhos dos homens. (ROUSSEAU, 1969, v. 4, pp. 458-9)

As leis sociais por convenção, portanto, não devem ser conhecidas porque Emílio é um homem físico do qual apenas as noções de necessidades e das coisas devem povoar seu espírito, exceção feita à noção de propriedade ${ }^{12}$, da qual a criança já tem uma certa compreensão porque

12 "Nenhuma sociedade pode existir sem a troca, nenhuma troca sem a medida comum, e nenhuma medida comum sem a igualdade. Assim toda a sociedade tem por primeira lei alguma igualdade convencional seja entre os homens seja entre as coisas. A igualdade 
esta ideia nasce de uma situação pré-racional (racionalidade entendida como a autonomia dos juízos, dos assentimentos e a dimensão ativa que atribui propriedades às coisas e faz comparações), como foi ilustrado na fábula do jovem aluno com Robert o jardineiro, vista no livro II do Emílio. A propriedade seria a única noção à qual ele poderia se ater porque ela nasce antes de quaisquer convenções, nasce do trabalho que empresta às coisas sua marca, seu uso, sua posse. A propriedade, por outro lado, claramente, só ganhará a legitimidade, na qual esteja formalmente assegurada e determinada juridicamente, depois da formalização e do reconhecimento intersubjetivo com o advento da sociedade contratual.

No que se refere à relação da propriedade com o dinheiro e o trabalho o genebrino só vê a convenção à sua frente, só vê acordos, só verifica o que foi politicamente estabelecido. Por essa via, ele se esquece de apresentar que a moeda, o dinheiro ${ }^{13}$ e, por isso, sua propriedade de ser equivalente geral de trabalho, que chega a admitir abstratamente, só se realiza materialmente, porque existe um trabalho que foi equiparado, trabalho que para a troca de mercadorias perderia sua natureza específica para ganhar generalidade abstrata, de acordo com o qual as mercadorias de natureza distintas poderiam ser igualadas e por isso trocadas: o trigo por pano, a troca do trabalho do agricultor com o trabalho do tecelão. Rousseau vê, apenas, como condição para que a equivalência exista a moeda, medida que seria fixada por convenção social. Por outro lado, ele não explica o que origina a moeda como expressão desta equivalência, o que nos leva a crer que a posição de Rousseau aqui fica limitada para explicar o fenômeno, porque não soube perceber no trabalho mesmo, quando colocado em condição de comparação, portanto, colocado na condição de equivalência, a origem explicativa tanto da troca de mercadorias, quanto, em seguida, da moeda. Nesse sentido, não teríamos de esperar somente a existência da moeda para igualar as coisas e trocar. Quanto a esse assunto, deveríamos esperar, a partir do pensador prussiano do século XIX, considerações mais precisas sobre a relação entre trabalho, produto do trabalho, propriedade e dinheiro.

convencional entre os homens, bem diferente da igualdade natural, torna necessária a lei positiva, ou seja, o governo e suas leis. Os conhecimentos políticos de uma criança devem ser nítidos e limitados: ele deve conhecer o governo apenas geralmente aquilo que se relaciona com o direito de propriedade do qual ele já tem alguma ideia" (ROUSSEAU, 1969, v. 4, p. 461).

13 "É difícil comparar imediatamente coisas de diferentes naturezas, o pano com o trigo, por exemplo. Mas quando encontramos uma medida com um, a saber a moeda, é fácil para o fabricante e ao trabalhador relacionar o valor das coisas que eles querem trocar com esta medida comum. Se tal quantidade de pano vale uma tal soma de dinheiro e que tal quantidade de trigo vale também a mesmo soma de dinheiro e em seguida que merceeiro recebendo esta farinha pelo seu pano faça uma troca equivalente. Assim, é pela moeda que os bens das espécies diversas tornam-se comensuráveis e podem se comparar" (ROUSSEAU, 1969, v. 4, 462). 
De toda a forma, a discussão sobre o trabalho, sobre a utilidade, a satisfação de necessidades e a propriedade, a despeito de toda a ultrapassagem teórica que ocorrerá nos anos subsequentes, existe na argumentação de Rousseau uma superação, seja no Emílio, seja no $2^{o}$ Discurso, do estado de natureza no qual o homem não pode permanecer se quiser aperfeiçoar-se. Reconhece-se no isolamento, uma vez realizadas as necessidades e as utilidades socialmente produzidas, o sinal da miséria humana, no qual o bastar-se a si mesmo não tem mais condições de efetivar-se, porque o indivíduo apenas é capaz de exercer sua individualidade se for condicionada pela alteridade social. Ou seja,

ao sairmos do estado de natureza, forçamos nossos semelhantes a saírem também, ninguém pode nele permanecer apesar dos outros e isso seria realmente dele sair ao querer nele permanecer na impossibilidade de nele viver, já que a primeira lei de natureza é o cuidado com a própria conservação. Assim se formam pouco a pouco no espírito de uma criança, as ideias de relações sociais, mesmo antes de poder ser membro ativo da sociedade. Emílio vê que para ter instrumentos para uso seu, é preciso que ele seja de uso dos outros, pelos quais ele possa obter a troca das coisas que lhe são necessárias com aquelas que estão em seu poder. (ROUSSEAU, 1969 v. 4, p. 467)

Quer dizer, as formas coletivas de relação demandam um comportamento dos indivíduos, tanto objetivamente quanto subjetivamente, ou intelectualmente, que nos forçam e lançam-nos para fora da condição de dispersão originária. Para realizar a própria natureza e com ela ser coerente e manter sua antropologia, Rousseau precisa incidir no homem a alteração, a possibilidade de ser agente de história, o outro contra o qual a natureza originária não pode mais fornecer barreiras, mas pode a natureza e a própria lei de conservação, oferecer a normatização para que sua realização social se dê de forma harmônica. O mundo da cultura funciona de modo a condicionar os indivíduos de tal forma que - o texto de Rousseau nos indica isso - o produto do trabalho e as necessidades criadas por força da dependência entre os membros da coletividade só podem ser criados, apropriados e difundidos socialmente.

Desse modo, a subjetividade humana passa a requerer uma coerência com essa nova forma de vida, no qual o registro das conquistas humanas não deve mais morrer ${ }^{14}$ com a pessoa que, supostamente, as

\footnotetext{
${ }_{14}$ Sobre o homem selvagem e a relação com a produção da vida no $2^{\circ}$ Discurso Rousseau assim se pronuncia: "Sua alma que não se agita em nada, entrega-se apenas ao sentimento de sua existência atual, sem qualquer ideia de futuro, ainda que próximo, e seus projetos, limitados como sua visão, se estendem com dificuldade até o fim do dia. Tal é ainda hoje, o grau de previsão do Caraíba: ele vende pela manhã seu leito de algodão e á tarde chora para comprá-lo de volta, por ter faltado a previsão que dele necessitaria na noite seguinte" (ROUSSEAU, 1964, v. 3, p. 144). Em seguida, sobre a situação do homem em relação ao seu estágio de desenvolvimento ele acrescenta mais adiante: "Concluamos
} 
criou. No $2^{\circ}$ Discurso o homem foi descrito acolhendo as modificações por que passou sua individualidade no concurso das transformações do gênero, quando passou a ser dependente. No Emílio, por sua vez, a educação em sua processualidade ilustra um caminho semelhante, que tem de percorrer o jovem aprendiz, para acolher com cuidado as diferenciações importantes da sociabilidade que o retiram da condição de miserável e ignorante, para a condição de ente de razão ainda capaz de manter o propósito de bastar-se a si mesmo, a ponto de verificar as verdadeiras necessidades no seio da sociabilidade, protegendo-se dos aspectos negativos das conquistas ou perdas das relações intersubjetivas. Pretendese fomentar, então, no contexto até demarcado no livro III do Emílio, uma subjetividade que consiga fazer a separação e classificação dos dados que foram coletados no momento mesmo da experiência e aqueles que se acham há mais tempo disperso nas mentes daqueles que podem já registrar a forma ideal e geral das coisas. Por sua vez, os materiais e os conteúdos da experiência sensível podem ter, é bom lembrar, origem relativa a experiência laboral como outra forma de expressão dessa sensibilidade, afeita a valores que podem avaliar melhor e de forma mais correta como o homem deve se comportar em meio social, para além das avaliações de opinião que o retirariam dessa condição de espontaneidade.

Ao introduzir o problema das desigualdades sociais com as quais terá de lidar Emílio, com as quais a hipótese do homem no puro estado de natureza teve de enfrentar no seu devir histórico, Rousseau fala das desigualdades sociais regulando-as, segundo entendemos, a partir da ordem e da normatização naturais. Desde seu início, a vida social expõe as diferenças entre os indivíduos: a riqueza, as posições sociais, a condição de vida, que padeceriam de uma origem comum, de uma "essência" comum, superadas pelas necessidades reais, tais como a sede, a fome, a morte, a fraqueza, a doença, que retiram dos homens em geral qualquer traço de distinção. O que propõe, então o genebrino, é ensinar ao homem o que é o homem mesmo, em sua condição existencial natural, de modo a prepará-lo para aquilo que pode vir a ser sem deixar de ser o que é fundamentalmente. A despeito das diferenças artificialmente produzidas, a

que, errando pelas florestas sem indústria, sem palavra, sem domicílio, sem guerra e sem laços, sem nenhuma necessidade de seus semelhantes, assim como sem nenhum desejo de o prejudicar, talvez sem jamais reconhecer a nenhum individualmente, o homem selvagem sujeito a poucas paixões e bastando-se a si mesmo, tem somente sentimentos e luzes próprias a esse estado, que ele sentia apenas verdadeiras necessidades, olhava apenas o que lhe interessava olhar e sua inteligência não progredia mais do que sua vaidade. Se por acaso fizesse uma descoberta, dificilmente poderia transmiti-la já que não conhecia sequer seus próprios filhos. A arte perecia com seu inventor. Não havia nem educação nem progresso, as gerações se multiplicavam inutilmente e cada partindo sempre do mesmo ponto, os séculos escoavam com toda a grosseria dos primeiros tempos; a espécie era velha e homem permanecia ainda uma criança" (ROUSSEAU, 1964, v. 3, p. 144). 
demarcação da autenticidade humana ocorre quando as coisas e as necessidades vitais mais fundamentais, não aquelas criadas com o critério do discurso opinativo, passam a regular o humanidade do homem.

A preocupação do autor com seu projeto de educação é interessante, porque, afinal, ele atém-se ao fato de que os homens podem ter deixado o estado de natureza, mas não devem deixar de ser naturais em certa medida, posto que ainda sentem as necessidades indeléveis da vida, muitas das quais esquecidas e superadas pelas necessidades aparentes, tais como o luxo e a lisonja. Nesse caso, incide sobre a formação de Emílio, assim como de qualquer um, a liberdade como autonomia, como independência. Não quer, com isso, que o homem deixe de viver na ausência do outro, ou alheio a quaisquer diferenças porque isso seria irreal, mas que não viva às custas do outro, a ponto de experimentar a maior das degenerações sociais a seu ver, o fraco explorando o forte, ou o rico dependente do pobre independente, que trabalha e vive do que realiza, embora expropriado de suas realizações.

De acordo com o ordenamento natural, as comparações fazem o conhecimento adaptar-se ao encontro da diversidade de coisas e indivíduos e produzir, sobre essas experiências, uma compreensão. Por sua vez, um discurso sobre a realidade objetiva é garantido pelo saber prático autêntico para a autossuficiência. Por outro lado, o ser social deve sua existência relativa, pois depende dos demais para o sustento de si. O trabalho é estimulado, valorizado, como condição do indivíduo para o gozo da vida social, embora determinados ofícios sejam mais desejáveis, dada sua natureza específica, porque seriam a expressão artificial da autossuficiência enquanto requisito da natureza. Subjetivamente, por outra via, quaisquer julgamentos subsequentes a essa condição estarão, de certa forma, corretamente sustentados pelo conhecimento proveniente daquele trabalho, daquele ofício que permite o homem saber quem ele é e o que pode fazer com relação a qualquer outro, com o qual, por ventura, tiver de se relacionar. Rousseau quer que

absolutamente Emílio aprenda um ofício. Um ofício honesto, pelo menos direis? O que significa essa palavra? Todo ofício útil ao público não seria honesto? Mas vamos em frente, eu errei: não é suficiente escolher um ofício útil, é preciso ainda que ele não requeira das pessoas que o exercem almas odiosas e incompatíveis com a humanidade. Assim, retornando à primeira palavra, tomemos uma profissão honesta, mas lembremo-nos sempre que não existe honestidade sem utilidade. (ROUSSEAU, 1969, v. 4, p. 473).

Essa correção, como salientamos, tem nas coisas o critério de distinção e qualificação do bom e o mal sociais, através do qual o trabalho e o saber prático ganham relevância moral. O trabalho, portanto, que produz efeitos úteis, por seu turno, converte-se em trabalho honesto, 
porque valorizar-se-ia em termos morais por aquilo que promove ao seu agente e ao gênero humano quando apropria de suas realizações. A partir de então, entende-se mais as considerações de Rousseau, segundo as quais a educação pelo corpo e pelo trabalho, enquanto a concretização e efetivação de experiências sensíveis com vistas a utilidades e satisfação de necessidades práticas de caráter social, ajudam a preparar um tipo de exercício espiritual mais afeito às abstrações, generalização e aos juízos. A experiência sensível, na concepção de outros autores do sensualismo, ao nosso ver, seria muda e silenciosa, qual um puro fenômeno. Isso se deve, acreditamos, porque ela é dissociada da prática, das fontes objetivas e sociais de conhecimento, cujo sentido é conferir aperfeiçoamento do indivíduo por sua realização e pelo produto do trabalho melhorar a condição de vida do gênero. Por esse aspecto, a avaliação do conhecimento é garantida porque ela é conferida pelo efeito prático que gera e, reflexivamente, como esse efeito interioriza-se no indivíduo como processo formador, educador, dando-lhe a inteligibilidade de uma noção peculiar ao postulado da autoconservação e de toda a moralidade que daí decorrerá posteriormente, ou seja: a compreensão do poder, que o saber fazer assegura. Quem sabe fazer, sabe o que pode.

Essa concepção de educação, de conhecimento e, fundamentalmente, de experiência sensível converte-se, por contribuir para uma preparação para o julgamento correto do indivíduo com relação ao que de fato importa nas relações como um todo, em modelo para a compreensão da outra forma da atividade prática humana, a moral, com a qual preocupa-se Rousseau desde as denúncias do $1^{\circ}$ Discurso. Quer dizer, "depois de ter começado a exercitar seu corpo e seus sentidos, começamos a exercitar seu espírito e seu julgamento. Enfim, reunimos o uso de seus membros ao de suas faculdades. Fizemos um ser ativo e pensante, nos resta para acabar o homem fazer um ser amável e sensível, ou seja, aperfeiçoar a razão pelo sentimento" (ROUSSEAU, 1969, v. 4, p. 481). Todo esse processo de formação e ainda de desenvolvimento físico e espiritual do homem acontece, no plano subjetivo e no plano relativo ao conhecimento, por exemplo, por etapas que respeitem um certo estágio psicofísico do homem e um grau de abstração e complexidade relacional do indivíduo com a realidade que o cerca, dependendo da fonte de informação associada com o tipo de educação: se a educação é feita de acordo com a natureza ou de acordo com as coisas, ou se pelos homens.

As análises que foram geradas, até o momento, preparam a transição para a outra abordagem da etapa de formação humana, já que o corpo e os sentidos fizeram-se atuantes para dar o instrumental a partir do qual o jovem homem deverá ser capaz de se orientar em torno de relações que não tem mais no trabalho e a utilidade das coisas, que não tem mais na 
"materialidade" do produto do trabalho, o "critério" último de avaliação da atividade humana por um lado, e de seus conhecimentos por outro. As análises ao final do livro III do Emílio, portanto, configuram o homem como ser sensível e trabalhador, para sua inserção no meio social e moral, para a qual os livros subsequentes forneceriam as instruções.

\section{Considerações finais}

Nesse contexto, há, ao nosso ver, da parte de Rousseau, um cuidado com as etapas de desenvolvimento e de conhecimentos associados, porque existiria uma vacuidade perigosa no plano da moralidade em direção à qual o jovem aluno se dirige: a vacuidade imaterial dos juízos e informações provenientes das opiniões e das aparências típicas do convívio social. Essas informações demandam, por seu turno, uma compressão clara do que o homem pode fazer, de um lado, como ser ativo no mundo que basta-se a si mesmo porque realiza seu modo de vida, e, de outro, do que ele pode fazer nas relações intersubjetivas que, em princípio, não são tão evidentes aos olhos de uma criança que deixa os braços da natureza para cair no colo da sociabilidade. Dependendo de como se configura essa sociabilidade, o artifício pode ser superestimado e as aparências podem assumir o papel de protagonista do jogo de forças entre os indivíduos, o que geraria, ao nosso ver, a perda do referencial da utilidade e da espontaneidade daquele ser que, de algum modo, pode ser autossuficiente. Se o ser perde o preparo do real valor das coisas e do mundo, que o condiciona para ter consciência do que se pode fazer, seria joguete das aparências sociais que nem sempre se orientam pelo valor da utilidade como condição para a honestidade. Útil poderia se transformar naquilo que os outros acham ser útil, aquilo que a opinião em geral acha ser útil. Se antes o referencial da utilidade alcança a objetividade das realizações humanas amplamente coerentes com o princípio de aperfeiçoamento, coerentes com o mundo da cultura de acordo com o qual ele pode fruir do produto dessas realizações e se realizar por meio delas, na sociabilidade em que as aparências e as opiniões então em cena tem-se o caminho aberto para a apropriação e o constrangimento generalizados dos indivíduos entre si, promovendo mais o conflito, em que todos estão em guerra com todos.

Por fim, o que tem o aluno ao final da jornada de educação na adolescência são os saberes originários da física, do confronto com os objetos, com as coisas que podem ser alteradas e criadas pelo homem por sua capacidade de diferenciar-se constantemente. Nesse âmbito, o que o jovem homem tem são as relações básicas e vitais com as coisas que o cercam e poucas relações com os homens. Por conseguinte, as ideias e abstrações ficam limitadas ao uso prático da esfera produtiva da vida, na 
qual as coisas são pensadas em vista daquilo que elas podem servir de satisfação das necessidades, também criadas a reboque das coisas. Com isso, as generalizações acham-se limitadas porque falta amplificá-las, processo que só será plenamente realizado com o aumento das idealizações, que a diversidade de "pontos de vista", a diversidade de opiniões e a ampla intersubjetividade, próprias das relações morais e sociais, pode proporcionar. Se o aluno tem todas as virtudes que se relacionam consigo próprio, faltando-lhe as noções sociais da virtude ${ }^{15}$, aspecto que só poderá conceber quando estiver inserido, de fato, nas relações sociais, ou nas relações sociais concebidas idealmente por Rousseau como um "romance".

O conhecimento sensível, por sua vez, que se tem nesse contexto, com forte influência da razão prática, é fruto de uma compreensão de como a utilidade essencial ao trabalho pode lançar luz sobre as propriedades das coisas e dar ao conhecedor maior noção da realidade porque sobre ela atua de forma a superar as carências das quais o homem padece eternamente. Pode-se dizer que o sensualismo assimilado por Rousseau livra-se da solidariedade, amplamente difundida, entre "o material" do conhecimento e as formas anímicas que sobre um conteúdo atuam. A comunidade existente entre as faculdades que pensam e organizam um conteúdo e o próprio conteúdo não poderiam, ao genebrino, parecer confundidas, reduzidas, ou simplificadas porque ele precisa da independência de certa atividade espiritual, de qualquer influência de origem externa e "corpórea", para que ele possa, depois, sugerir a tema da liberdade, do erro, e das características de distinção específica do ser humano. Essas distinções teriam contribuições do pensamento produzido pela faculdade de julgar e o entendimento, que faltam ao âmbito do saber sensivelmente determinado no estágio formativo dos três primeiros livros do Emílio.

\section{Referências bibliográficas}

GROSSMAN, Mordecai. The philosophy of Helvetius: with special emphasis on the educational implications of sensationalism. Kessinger Publishing, 2008.

\footnotetext{
15 "Emílio tem somente conhecimentos naturais e puramente físicos. Nem sabe ainda o nome da história, nem o que é metafísica e moral. Ele conhece as relações essenciais do homem com as coisas, mas nenhuma das relações morais do homem com o homem. Ele sabe pouco generalizar as ideias, pouco faz abstrações. Ele vê qualidades comuns à certos corpos sem raciocinar sobre suas qualidades em si mesmas. (...) Em uma palavra, Emílio tem da virtude tudo o que se relaciona consigo mesmo. Para ter também as virtudes sociais falta-lhe conhecer as relações que as exigem, faltam-lhe unicamente as luzes que seu espírito está prestes a receber" (ROUSSEAU, 1969, v. 4, pp. 487-8).
} 
HELVETIUS, Claude Adrien. De L'Esprit. Paris: Adamant Media Corporation, 2005.

. De L'homme, de ses facultés intellectuelles et de son éducation. Paris: Librairie Arthème-Fayard, 1989.

MARUYAMA, Natalia. A moral e a filosofia política de Helvetius: uma discussão com J.-J. Rousseau. São Paulo: Associação Editorial Humanitas/Fapesp, 2005.

ROUSSEAU, Jean Jaques. Oeuvres completes. Ed. publieé sous la direction de Bernard Gagnebin et Marcel Raymond. Paris: Gallimard, 1959-95. 5v.

. Émile ou De l'éducation. Paris: Éditions Garnier Frères, 1961.

- Discurso sobre a origem e os fundamentos da desigualdade

entre os homens. Trad. Lourdes Santos Machado. 2. ed. São Paulo: Abril Cultural, 1978.

. Discurso sobre a origem e os fundamentos da desigualdade entre os homens. Trad. Iracema Gomes Soares e Maria Cristina Roveri Nagle. Brasília: Editora Universidade de Brasília, 1985.

. Emílio ou Da educação. Trad. Roberto Leal Ferreira. 3. ed. São Paulo: Martins Fontes, 2004.

- Carta a Christophe de Beaumont e outros escritos sobre a religião e a moral. José Oscar de Almeida Marques (Org.). São Paulo: Estação Liberdade, 2005.

- Cartas escritas da Montanha. Trad. e notas Maria Constança Peres Pissarra. São Paulo: Educ/Unesp, 2006.

. Ensaio sobre a origem das línguas. Trad. Fulvia M. L. Moretto.

Campinas: Editora Unicamp, 2008.

VARGAS, Yves. Introduction à l'Émile de Rousseau. Paris: PUF, 1995.

Como citar:

CAMPOS, Henrique Segall Nascimento. Sensibilidade, educação e trabalho em $O$ Emílio de Rousseau. Verinotio - Revista on-line de Filosofia e Ciências Humanas, Rio das Ostras, v. 25, n. 1, pp. 210-39, abr. 2019.

Data de envio: 15 ago. 2018

Data de aceite: 13 jan. 2019 